\title{
THE ASSESSMENT OF SPATIAL TRANSFERABILITY OF A DISTRIBUTED HYDROLOGICAL MODEL PARAMETERS IN DIFFERENT PHYSIOGRAPHIC REGIONS OF NEPAL
}

\author{
Sangam SHRESTHA ${ }^{1}$, Khada Nanda DULAL ${ }^{1}$, Satish BASTOLA ${ }^{1}$, Hiroshi \\ ISHIDAIRA ${ }^{2}$, Futaba KAZAMA ${ }^{2}$ and Kuniyoshi TAKEUCHI ${ }^{3}$ \\ ${ }^{1}$ Member of JSCE, PhD Student, University of Yamanashi \\ (4-3-11, Takeda, Kofu, Yamanashi, 400-8511, Japan) \\ ${ }^{2}$ Member of JSCE, Associate Professor, University of Yamanashi \\ (4-3-11, Takeda, Kofu, Yamanashi, 400-8511, Japan) \\ ${ }^{3}$ Member of JSCE, Professor, University of Yamanashi \\ (4-3-11, Takeda, Kofu, Yamanashi, 400-8511, Japan)
}

\begin{abstract}
This study focuses on assessment of the spatial transferability of parameters of a physically based distributed hydrological model, Blockwise use of TOPMODEL with Muskingum-Cunge routing (BTOPMC), to simulate the runoff in different physiographic regions of Nepal. The model was calibrated and validated using different time series data of six basins located in different physiographic regions of Nepal. The model parameters obtained after calibration from six basins were averaged and then applied in other two data limited basins for the jackknife validation of regionalization scheme. The model performance was evaluated by Nash-Sutcliffe efficiency, volume bias and qualitative comparison of observed and simulated hydrograph. The result of model calibration and validation in six basins shows that the model performs well in simulating runoff volume and capturing the seasonal and annual variations. Similarly, the result of model parameter transfer shows that the BTOPMC model parameters can be used to simulate the runoff components in ungauged basins.
\end{abstract}

Key Words : hydrological model, calibration, runoff, transferability, Nepal

\section{INTRODUCTION}

Several hydrological models have been developed to assist in understanding of hydrologic system and water resources management. These models can simulate water management strategies that satisfy the demands of different users, while mitigating deleterious effects on riparian ecosystems. According to the process description, these models can be classified into three categories: empirical (black box), conceptual and physically-based models. According to the spatial representation, the hydrological models are either lumped or distributed. However, in most applications, all are lumped temporally, e.g. when using daily or even hourly time steps. To account for spatial and temporal variations, it is necessary for physically based distributed hydrological modelling. But one of the main discussions in the last decade on distributed models has been on the value of physically based versus conceptual process descriptions ${ }^{1,2,2,3}$. A major problem with physically-based distributed models is that in practice they tend to function as lumped conceptual models due to lack of data and limitations in computer processing time. However, in the mean time introduction of geographic information system (GIS), remote sensing (RS) technologies along with the immense utilization of powerful computers in 
this field and many data which are required to run the model are available freely in the global public domain makes the physically based distributed hydrological modelling more reliable. When the physically-based distributed models were introduced they were most optimistically thought of as being models that could be used without prior calibration, because all model parameters should be identifiable from field data ${ }^{4}$. As a logical follow up along this line of thought Ewen and Parkin (1996) s) suggested a "blind" model validation procedure, where no calibration was allowed. In practice, however, partly due to lack of the necessary detailed data or due to a too coarse model grid resolution, it is usually necessary to identify some of the parameters through calibration and recently there are some initiatives to study the transferability of hydrological model parameters between the basins based on the hydrological similarity ${ }^{6}$ after the Prediction in Ungauged Basins (PUB) initiative of the International Association of Hydrological Sciences (IAHS) ${ }^{7}$ where the objective is to predict basin hydrologic processes, e.g. river discharge, using limited information available for any basin, and to reduce uncertainties associated with such prediction $^{8}$.

In Nepal, only few studies have been conducted ${ }^{9,10,11)}$ to evaluate the suitability of distributed hydrological models for water resources management. Therefore, this study focuses on assessment of the spatial transferability of parameters of a physically based distributed hydrological model, Blockwise use of TOPMODEL with Muskingum-Cunge routing (BTOPMC), to simulate the runoff in different physiographic regions of Nepal.

\section{METHODOLOGY}

\section{(1) Study area and data sets}

The study area consists of eight river basins located in Siwalik and Hill physiographic regions of Nepal (Fig. 1). The drainage area of the basins ranges from $363 \mathrm{~km}^{2}$ to $5150 \mathrm{~km}^{2}$. All of these rivers are located in the Southern part of Nepal and originated from the Middle Mountains. The source of runoff for these rivers is monsoon rainfall and groundwater. About $80 \%$ of rainfall falls in monsoon period (July-Sep) and the rest of the period is very dry. The climate of these areas varies with altitude: tropical climate in the southern plain areas, sub-tropical climate in the Siwalik Hills and temperate climate in the Middle Mountains. The major land uses of the basins are cropland and forest.

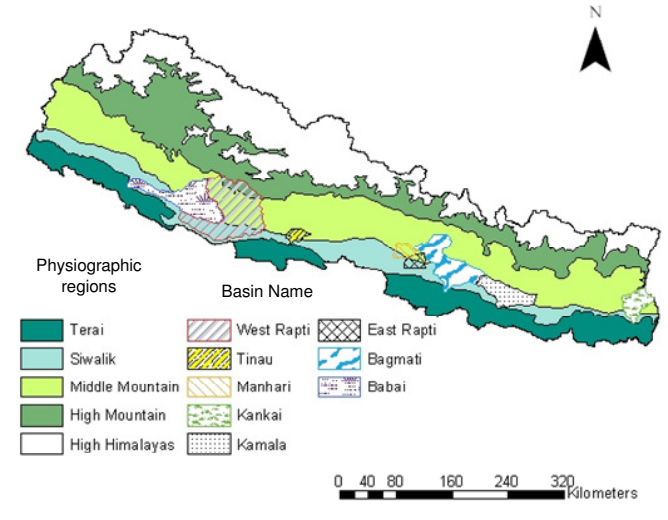

The data sets required for the study were either obtained from local government organizations or downloaded freely from public domains (Table 1).

Table 1. Data availability of the basins used in this study

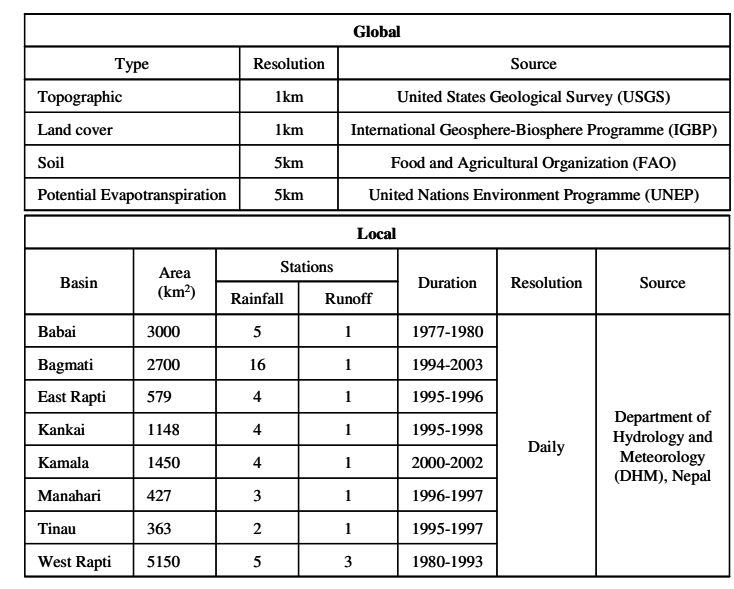

The landuse, soil, and PET data are the representative of 1992-1993, 1995 and 1920-1980 respectively.

\section{(2) Model description}

The BTOPMC model was used to simulate runoff for this study. BTOPMC stands for "Blockwise use of TOPMODEL with Muskingum-Cunge routing". This is a physically based distributed hydrological model developed at the University of Yamanashi, $\mathrm{Japan}^{12), 13}$. BTOPMC is an extension of TOPMODEL concepts $^{1)}$, which is developed in order to overcome the limitations of using the TOPMODEL for large river basins. For large river basins, spatial heterogeneity and timing of flow to outlet are the important factors. For representing spatial variability in BTOPMC, a basin is composed of grid cells, 
which can be divided into sub-basins, where each sub-basin is considered as a block or a unit. To consider timing of flow, flow from each grid cell is routed to the outlet using Muskingum-Cunge routing method. The flow generation mechanism of BTOPMC is based on TOPMODEL concepts. TOPMODEL is based on a saturation-excess runoff mechanism, in which the saturation zone is called contributing area. The difference in TOPMODEL and BTOPMC is that in TOPMODEL the water table is spatially lumped over a basin, while in BTOPMC the lumping is done for a grid scale.

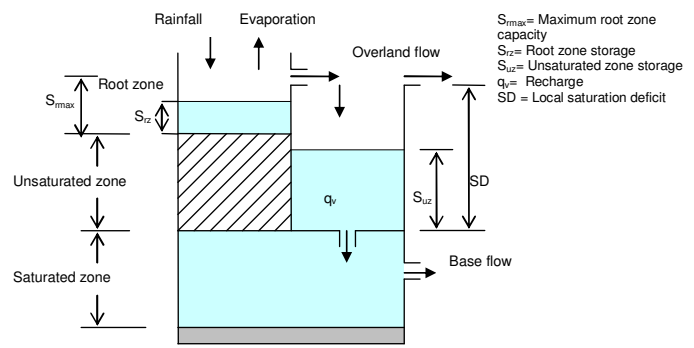

Fig. 2 Vertical soil profile in BTOPMC for each grid cell

In BTOPMC, the soil profile of a grid cell is divided into three layers (root, unsaturated and saturated zones) as shown in Fig. 2. Rainfall on the $i^{\text {th }}$ grid cell is first received by the root zone storage which is subjected to evaporation. The unsaturated zone receives the overflow from the root zone storage and the saturated zone receives flow from the unsaturated zone. The outflow from the saturated zone constitutes base flow. The overland flow is generated when the unsaturated zone storage exceeds the local storage deficit. The discharge in each cell is composed of both overland flow and base flow. Both are dependent on local saturation deficit.

The basic equations describing the concept of BTOPMC are presented below.

Within sub-basins, groundwater is mutually shared and discharges to nearby stream within grid cell $i$. The groundwater flow equation is

$q_{i}=T_{0} \exp \left(-S D_{i} / m\right) \tan \beta_{i}$

where $q_{i}$ is the ground water flow per unit contour length, $T_{0}$ is defined as saturated transmissivity $\left(\mathrm{m}^{2} / \mathrm{h}\right)$, namely the lateral transmissivity when the soil profile is just saturated at the ground surface, $S D_{i}$ is local saturation deficit (m), $m$ is a decay factor of lateral transmissivity with respect to saturation deficit $(\mathrm{m}), \beta$ is the local slope angle, and $\tan \beta_{i}$ is the hydraulic gradient.

For each grid cell $i$, $q_{i}=r a_{i}$

where $q_{i}$ is the ground water flow per unit contour length, $r$ is the recharge rate $(\mathrm{m} / \mathrm{h})$ and $a_{i}$ is the upstream contributing area per unit contour length $\left(\mathrm{m}^{2} / \mathrm{m}\right)$ that drains through point $i$.

From equation (1) and (2), the distribution of local saturation deficit, $S D_{i}$ is derived as

$S D_{i}=\overline{S D}+m\left(\gamma-\gamma_{i}\right)$

where $\overline{S D}$ is average saturation deficit in the catchment, $\gamma_{i}$ is soil-topographic index $\left(\gamma_{i}=\ln \left(a_{i} / T_{0} \tan \beta_{i}\right)\right)$ and $\gamma$ is the catchment average of the soil-topographic index.

The following are the parameters of BTOPMC model:

$T_{0}$ : the saturated soil transmissivity, which describes the potential rate of lateral flow for a completely saturated soil for a given hydraulic gradient.

$m$ : the decay factor of transmissivity, which describes how the actual transmissivity decreases when the soil is not saturated.

$S_{\text {rmax }}$ : the maximum root zone capacity, which represents the plant available soil moisture capacity as well as interception capacity of the canopy.

$n_{0}$ : the roughness factor for a block, which is used as a scaling parameter to compute Manning's roughness for routing.

\section{(3) Model parameter estimation procedure}

It is difficult to implement an automatic optimization technique for a distributed hydrological model like BTOPMC. Therefore, parameters of the model in this study were estimated by calibrating the model manually.

The calibration of four model parameters; $T_{0}, m$, $S_{\text {rmax }}$ and $n_{0}$ were carried out. For distributing $n_{0}$ value to each river segment, the following expression is used in BTOPMC.

$$
n_{i}=n_{0}(\mathrm{k})\left[\tan \beta_{\mathrm{i}} / \tan \beta_{0}(\mathrm{k})\right]^{1 / 3}
$$

where $n_{i}$ is equivalent Manning roughness coefficient of river segment $i, \tan \beta_{\mathrm{i}}$ is local topographic gradient and $\tan \beta_{0}$ is the topographic gradient at the outlet of sub-basin $k . T_{0}$ in BTOPMC can be derived from soil types, where weighted soil texture is used to represent spatial heterogeneity ${ }^{15}$.

$$
T_{0}=T_{0} C l \times U_{c l}+T_{0} S a \times U_{s a}+T_{0} S i \times U_{S i}
$$


where $T_{0} C l, T_{0} S a, T_{0} S i$ are $T_{0}$ value for clay, sand and silt, and $U_{c l}, U_{s a}$ and $U_{s i}$ are the percentages of clay, sand and silt present in each grid, which was obtained from the FAO soil data. Calibrating $T_{0}$ for clay, sand and silt gives $T_{0}$ value of soil for each grid cell. $S_{\text {rmax }}$ in BTOPMC is based on land use class. IGBP land use data was reclassified into four classes (deep rooted, shallow rooted, shallow rooted and irrigated, and impervious) in order to improve identifiability and improve computation efficiency, and $S_{\text {rmax }}$ value for the reclassified land use was calibrated.

In this study, The BTOPMC model is calibrated and validated for six basins. Since all six basins are located in Siwalik and Middle Mountain regions and considering temporal rainfall distribution (80\% rainfall in summer monsoon period), climate zone (tropical to temperate) and land use (mainly forest, agriculture and grassland), the six basins used in the study are taken as a set of homogeneous basins for developing a regional model. The regional models were constructed using average of the calibrated model parameters for all basins considered. Then the average model parameters were transferred into two basins, named Tinau and Manohari to simulate the runoff. These two basins were selected for the validation of regional scheme because these have limited data and calibration can not be done effectively.

\section{(4) Model Performance indicator}

The first indicator of model performance considered is Nash-Sutcliffe Efficiency (NSE). The Nash Sutcliffe efficiency (NSE) given by Eq. (6), a normalized form of Root Mean Square Error (RMSE) is commonly adopted for evaluating the simulated hydrograph.

$$
N S E=1-\frac{\sum_{i=1}^{n}\left[Q_{o b s, i}-Q_{s i m, i}\right]^{2}}{\sum_{i=1}^{n}\left[Q_{o b s, i}-\bar{Q}_{o b s}\right]^{2}}
$$

where $\bar{Q}_{\text {obs }}$ is the average Observed discharge, $Q_{\text {sim }}$ is the simulated discharge, $Q_{o b s}$ is the observed discharge and $n$ is the number of time step. Based on sum of error variances, the NSE is sensitive to difference in both maximum values and timing of flood peak. Therefore to check the mass balance, another indicator, called volume bias (VB) is also computed, which is given by:

$V B=\frac{\sum\left(Q_{s i m}-Q_{o b s}\right)}{\sum Q_{o b s}}$ where, $Q_{\text {sim }}$ is simulated discharge and $Q_{o b s}$ is observed discharge.

\section{RESULTS AND DISCUSSIONS}

\section{(1) Model calibration and validation}

The BTOPMC model was calibrated and validated for six basins with different time series of available data (Table 2). The calibrated model parameters are outlined in Table 3 . The parameters values are inside the range recommended by Ao et al., 2006 ${ }^{14}$. The ranges are similar in all basins except $n_{0}$ for Bagmati basin, $m$ for East Rapti basin and $T_{0}$ for all basins. It might be possible to obtain similar values for all parameters for all basins during calibration at a cost of model performances. But in the regionalization process, only those parameters set are choosen which gives the higest model performance. The difference may be attributed to the specific catchment characteristics. For example, parameters $m, n_{0}$ and $T_{0}$ are largely influenced by soil type and land cover in the basin. However, it needs a detail investigation on relating model parameters to catchement attributes, which is not under the scope of this study. The performance of the model in simulating runoff are outlined in Table 4.

Table 2. Calibration and validation data period

\begin{tabular}{|l|c|c|}
\hline \multicolumn{1}{|c|}{ Basin } & Calibration & Validation \\
\hline Babai & $1977-1978$ & $1979-1980$ \\
\hline Bagmati & $1994-1997$ & $1998-1999$ \\
\hline East Rapti & 1995 & 1996 \\
\hline Kamala & $2000-2001$ & 2002 \\
\hline Kankai & $1995-1997$ & 1998 \\
\hline West Rapti & $1988-1990$ & $1991-1993$ \\
\hline
\end{tabular}

The NSE ranges from $31 \%$ to $71 \%$ for calibration period and from $41 \%$ to $71 \%$ in validation period. Similarly, the VB ranges from $-0.6 \%$ to $19 \%$ for calibration period and -3.4 to $34 \%$ in validation period. In this study, NSE more than $60 \%$ and VB within $\pm 20 \%$ are considered to be acceptaible model performance. Performance of calibrated model parameters measured as NSE for the Bagmati, the West Rapti and the Kankai is acceptable, for other three basins were not good. For validation period, NSE is good for the Bagmati, and the East Rapti while it is not good for other four basins. Looking at $\mathrm{VB}$, the model performed better for all basins during calibration, while for validation period the model performance is good for four basins except the East Rapti and the Babai.

The model performance was also evaluated by comparing the observed and simulated hydrographs 
(shown only for Bagmati basin as a typical case, Fig.

East Rapti basin.

3).

Table 3. Calibrated model parameters

\begin{tabular}{|l|c|c|c|c|c|c|c|c|c|}
\hline \multirow{2}{*}{ Basin } & \multirow{2}{*}{$\mathrm{m}(\mathrm{m})$} & \multirow{2}{*}{$\mathrm{n}_{0}$} & \multicolumn{4}{c|}{$\mathrm{S}_{\mathrm{rmax}}(\mathrm{m})$} & \multicolumn{3}{c|}{$\mathrm{T}_{0}\left(\mathrm{~m}^{2} / \mathrm{h}\right)$} \\
\cline { 4 - 11 } & & & $\mathrm{DR}$ & $\mathrm{SR}$ & SRI & IMP & Clay & Sand & Silt \\
\hline Babai & 0.04 & 0.01 & 0.03 & 0.02 & 0.01 & 0.0001 & 0.5 & 4 & 2 \\
\hline Bagmati & 0.06 & 0.001 & 0.03 & 0.02 & 0.01 & 0.0001 & 2 & 5 & 4 \\
\hline East Rapti & 0.25 & 0.01 & 0.03 & 0.02 & 0.01 & NA & 1 & 7 & 4 \\
\hline Kamala & 0.07 & 0.02 & 0.03 & 0.02 & 0.01 & NA & 3 & 5 & 4 \\
\hline Kankai & 0.03 & 0.01 & 0.03 & 0.02 & 0.01 & NA & 0.5 & 1.5 & 1 \\
\hline West Rapti & 0.05 & 0.01 & 0.03 & 0.02 & 0.01 & 0.0001 & 1 & 5 & 3 \\
\hline
\end{tabular}

Table 4. Model performance during calibration and validation

\begin{tabular}{|l|c|c|c|c|}
\hline \multirow{2}{*}{ Basin } & \multicolumn{2}{|c|}{ NSE $(\%)$} & \multicolumn{2}{c|}{ VB $(\%)$} \\
\cline { 2 - 5 } & $\begin{array}{c}\text { Calib- } \\
\text { ration }\end{array}$ & $\begin{array}{c}\text { Valid- } \\
\text { ation }\end{array}$ & $\begin{array}{c}\text { Calib- } \\
\text { ration }\end{array}$ & $\begin{array}{c}\text { Valid- } \\
\text { ation }\end{array}$ \\
\hline Babai & 31.7 & 41.6 & -18.9 & 34.0 \\
\hline Bagmati & 68.1 & 66.3 & -0.6 & 11.2 \\
\hline East Rapti & 58.0 & 71.5 & -13.7 & 20.1 \\
\hline Kamala & 40.2 & 55.9 & 19.2 & 10.6 \\
\hline Kankai & 63.3 & 49.4 & 7.6 & 12.5 \\
\hline West Rapti & 70.7 & 58.1 & -8.9 & -3.4 \\
\hline
\end{tabular}
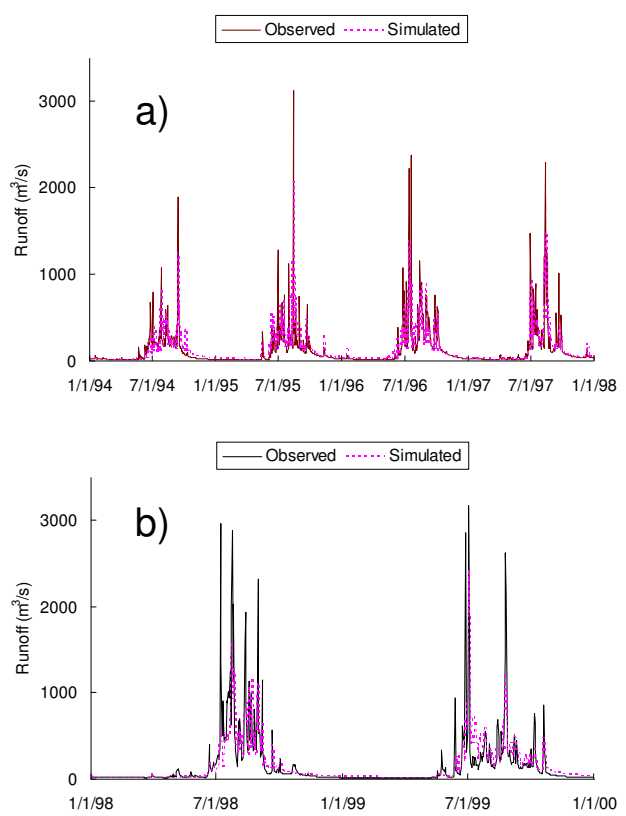

Fig. 3 Comparison between observed and simulated runoff in Bagmati basin during a) calibration and b) validation period (as a typical case).

In most of the basins, the model captured all the variations in seasonal and annual variations in runoff. However, the peak flow was underestimated for the Babai, the Kankai and the West Rapti. Low flows are captured well for five basins, while it was underestimated for the recession period in case of the

\section{(2) Evaluation of parameter transferability}
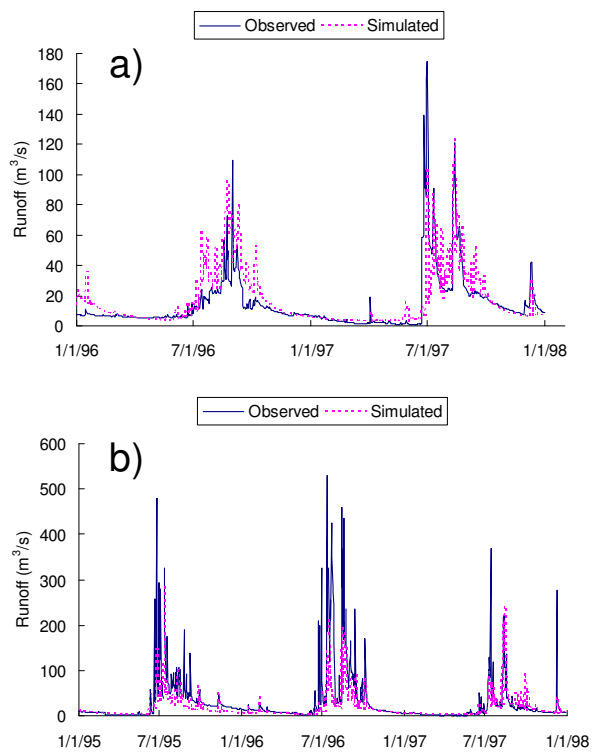

Fig. 4 Comparison between observed and simulated runoff in a) Manhari and b) Tinau basins.

The calibrated model parameters (Table 3) of six basins were averaged to construct the regional models to test the transferability into other basins. The averaged parameters are: $m=0.08 \mathrm{~m}, n_{0}=0.01$, $S_{\text {rmax }}$ for DR $=0.03 \mathrm{~m}, S_{\text {rmax }}$ for $\mathrm{SR}=0.02 \mathrm{~m}, S_{\text {rmax }}$ for $\mathrm{DRI}=0.01 \mathrm{~m}, S_{\text {rmax }}$ for IMP $=0.0001 \mathrm{~m}, T_{0}$ for clay $=$ $1.3 \mathrm{~m}^{2} / \mathrm{h}, T_{0}$ for sand $=4.6 \mathrm{~m}^{2} / \mathrm{h}, T_{0}$ for silt $=3.0 \mathrm{~m}^{2} / \mathrm{h}$. These averaged parameters were applied to simulate the runoff in Manhari and Tinau basins. The NSE are $38.3 \%$ and $33.4 \%$ and $\mathrm{VB}$ are $14 \%$ and $-21 \%$ for Manhari and Tinau basins respectively. The observed and simulated hydrograph were compared and it is observed that the model could capture the seasonal and annual variations in both basins (Fig. 4).

To test whether there is loss in performance of model while transferring average model parameters 
(called spatial loss in model efficiency), an independent calibration was performed in both basins. Independent calibration was performed in in both basins assuming that the available data set is sufficient for model performance evaluation. The NSE are $39.2 \%$ and $34.0 \%$ and VB are $16.2 \%$ and $-21.2 \%$ for Manhari and Tinau basins respectively. It was observed that the calibrated parameters were similar and resulted in similar performances i.e. loss in model performance has not occurred even after using average model parameters of six basins. Therefore, it was assumed that the transferability of parameters were successful though the model performance were poor. The poor performance of model may be attributed to errors in data measurement, especially in rainfall and discharge data. In addition, there might be uncertainty in spatial variability of precipitation due to the sparse network of raingauges as compared to the drainage area in both basins.

\section{CONCLUSION}

A physically based distributed hydrological model, Blockwise use of TOPMODEL with Muskingum-Cunge routing (BTOPMC), was calibrated and validated in six river basins located in different physiographic regions of Nepal. The calibrated model parameters were then averaged and applied to other two data limited basins to assess the spatial transferability of the model parameters for the simulation of runoff. The performance of the models are good in most of the basins during calibration and validation phase. The model performance is only marginally less as compared to average performance of calibration and validation phase while average model parameters were transferred spatially. However, the results of independent calibration shows that the loss in model performance is due to the error in measurement of data. Since the BTOPMC has only few parameters, with physical meanings, to be calibrated, there is ample opportunity to apply it in ungagued basins for the water resources management. However, it is recommended to do analysis in uncertainty in runoff simulations due to input data and uncertainty in model parameters derived from regionalization schemes to judge it's reliability for future use.

ACKNOWLEDGEMENT: The authors would like to extend sincere thanks to $21^{\text {st }}$ Century Center of Excellence (COE), Universty of Yamanashi providing the opportunity to conduct this study. parameterizations and scale-dependent hydrological models. Hydrological Processes, 9 (5-6):507-525, 1995.

2) Grayson, R.B., Moore, I.D. and McHahon, T.A. : Physically based hydrologic modelling. Is the concept realistic? Water Resources Research, 28(10), 2639-2658, 1992.

3) Refsgaard, J.C., Storm, B. and Abbott, M.B.: Comment on 'A discussion of distributed hydrological modelling' by K. Beven . In: Distributed Hydrological Modelling, Abbott, M.B. and Refsgaard, J.C. (Eds). Kluwer Academics Publisher, 279-287, 1996.

4) Abbott, M. B., Bathurst, J. C., Cunge, J. A., O’Connell, P. E., and Rasmussen, J.: An introduction to the Europe Hydrological System - Système Hydrologique Européen (SHE). History and philosophy of a physically based, distributed modeling system. Journal of Hydrology, 87:45-59, 1986.

5) Ewen, J.and Parkin, G.: Validation of catchment models for predicting land-use and climate change impacts. Journal of Hydrology, 175 (1-4), 583-594, 1996.

6) Duan, Q., Schaake, J., Andreassian, V., Franks, S., Gupta, H.V.,Gusev, Y.M., Habets, F., Hall, A., Hay, L., Hogue, T., Huang,M., Leavesley, G., Liang, X., Nasonova, O.N., Noilhan, J.,Oudin, L., Sorooshian, S., Wagener, T., Wood, E.F.: Model parameter estimation experiment (MOPEX): overview and summary of the second and third workshop results, Journal of Hydrology, 320 (1-2):3-17, 2006.

7) Sivapalan, M., Takeuchi, K., Franks, S.W., Gupta, V.K., Karambiri, K., Lakshmi, V., Lianf, X., McDonnell, J.J., Mendiondo, E.M., O'Connell, P.E., Oki, T., Pomeroy, J.W., Schertzer, D., Uhlenbrook, S. and Zehe, E.: IAHS Decade on Prediction in Ungauged Basins (PUB), 2003-2012: Shaping an exciting future for the hydrological sciences, Hydrological Sciences Journal, 48(6):857-880, 2003.

8) Gan T.Y.and Burges, S.J.: Assessment of soil-based and calibrated parameters of the Sacramento model and parameter transferability. Journal of Hydrology, 320:117-131, 2006.

9) Shrestha, R., Takara, K., Tachikawa, Y., Jha, R.N.: Water resources assessment in a poorly gauged mountainous catchment using a geographical information system and remote sensing. Hydrological Processes, 18:3061-3079, 2004.

10) Shrestha, S., Babel, M.S. Das Gupta, A and Kazama, F.: Evaluation of Annualized Agricultural Non Point Source model for a Watershed in the Siwalik Hills of Nepal. Environmental Modelling and Software, 27(4):961-975, 2006.

11) Dulal K.N., Takeuchi, K. and Ishidaira, H.: An assessment of uncertainty in precipitation on runoff simulation, Annual Journal of Hydraulic Engineering, 50:91-96, 2006.

12) Takeuchi, K., Ao, T.Q., Ishidaira, H.: Introduction of block-wise use of TOPMODEL and Muskingum-Cunge method for the hydro-environmental simulation of a large ungauged basin. Hydrological Sciences Journal, 44: 633-646, 1999.

13) Hapuarachchi, H.A.P., Magome, J, Struthers, I., Takeuchi K.: WinBTOPMC. University of Yamanashi, Kofu, Japan, 2004 (Unpublished).

14) Hapuarachchi, H. P., Kiem, A. S., Takeuchi, K., Ao, T., Magome, J. and Zhou, M.: Applicability of the BTOPMC Model for Predictions in Ungauged Basins, Int. Conf. Sustainable Water Resources Management in Changing Environment of Monsoon Region, Colombo, Sri Lanka, 2004.

15) Ao, T. Q., Ishidaira, H., Takeuchi, T., Kiem, A.S., Yoshitani, J., Fukami, K., Magome,J.: Relating BTOPMC model parameters to physical features of MOPEX basins. Journal of Hydrology, 320:84-102, 2006.

(Received September 30, 2006)

\section{REFERENCES}

1) Beven K.: Linking parameters across scales - sub grid 